\title{
EFECTUL NANOPARTICULELOR ZnO ASUPRA CONTIINUTULUI DE PIGMENȚI CAROTENOIZI LA TULPINA DE LEVURI Rhodotorula gracilis CNMN-Y-30
}

\author{
Beșliu Alina, Usatîi Agafia, Efremova Nadejda \\ Institutul de Microbiologie și Biotehnologie, Chişinău, Republica Moldova \\ e-mail: besliu.imb@gmail.com
}

În ultimele decenii microorganismele sunt folosite pe larg de comunitatea științifică pentru studierea biodiversității și ca obiecte biotehnologice de valoare. Obținerea preparatelor microbiologice reprezintă un domeniu actual care necesită noi surse de materie primă pentru elaborarea produselor alimentare biologic active, medicamentoase, cosmetologice, profilactice și farmaceutice. În calitate de surse cu potențial înalt sunt studiate levurile pigmentate din genul Rhodosporidium, care au capacitatea de a sintetiza importante substanțe bioactive şi în special pigmenți carotenoizi. Carotenoizii sunt un grup omnipresent de pigmenți izoprenoizi, formați din 40 atomi de carbon derivați prin biosinteza a două generații de geranil-transferaza pirofosfat, structura ciclică a atomilor de carbon le oferă proprietăți antioxidante înalte care protejează membrana, captând radicalii $\mathrm{O}^{2}$ și peroxil (Porter și colab., 1981). Mai mult, unele carotenoide sunt precursori ai vitaminei $\mathrm{A}$, în ceea ce privește sănătatea umană, au fost creditate pentru reducerea bolilor precum cancerul, bolile cardiovasculare, degenerescența maculară și cataracta (Oguz, 2017). De asemenea, carotenoizii dețin un rol important pentru utilizarea ca coloranți naturali în industria alimentară (Ibrahim și colab., 2015). Nu mai puțin actuală însă este selectarea factorilor care ar putea exercita efect stimulator asupra biosintezei carotenoizilor. În ultimii ani o atenție deosebită se oferă cercetărilor utilizării nanoparticulelor oxizilor metalici, în special oxidului de zinc $(\mathrm{ZnO})$ în procesul de cultivare a microorganismelor. Conform datelor din literatura de specialitate nanoparticulele pot exercita efecte stimulatorii dar și inhibitorii asupra microrganismelor, care însă depind de compoziția chimică, dimensiunea, concentrația, tipul și forma nanoparticulelor (Johnson et. al., 2015; Cheng et. al., 2017).

În această lucrare sunt prezentate rezultatele influenței nanoparticulelor $\mathrm{ZnO}$ cu dimensiunea de $<50 \mathrm{~nm}$ și $<100 \mathrm{~nm}$ în concentrații de la $0.5 \mathrm{mg} / \mathrm{L}$ la $10 \mathrm{mg} / \mathrm{L}$ asupra conținutului de pigmenți carotenoizi intracelulari $\beta$ - caroten, torulina și torularodina la tulpina de levuri pigmentate Rhodosporidium toruloides CNMN-Y-30. Cantitatea de pigmenți carotenoizi din biomasa levuriană s-a determinat spectrofotometric la lungimile de undă: beta-carotenul $453 \mathrm{~nm}$, torulina $480 \mathrm{~nm}$, torularodină 507 nm (Tamaș și colab., 1986; Fregova și colab., 1994).

Experiențele efectuate au demonstrat că conținutul de pigmenți carotenoizi ai tulpinii de interes biotehnologic, la cultivare pe mediul YPD în prezența nanoparticulelor $\mathrm{ZnO}$ se modifică în funcție de dimensiune și concentrațiile utilizate. Cercetările au pus în evidență efect pozitiv al procesului de biosinteză al pigmenților carotenoizi în variantele în care s-au aplicat nanoparticule $\mathrm{ZnO}(<50 \mathrm{~nm})$ în concentrațiile de la $5 \mathrm{mg} / \mathrm{L}$ până la $10 \mathrm{mg} / \mathrm{L}$. Cantitatea de pigmenți acumulați în biomasa levuriană crește cu până la 29\%, față de proba control. Analiza efectului nanoparticulelor $\mathrm{ZnO}(<50 \mathrm{~nm})$ asupra conținutului de $\beta$-caroten la aplicarea concentrațiilor de $5.0-10 \mathrm{mg} / \mathrm{L}$, demonstrează o creștere de 12$39 \%$. Un răspuns similar a fost obținut pentru ceilalți doi pigmenți analizați torulina și torularodina cantitatea cărora crește cu 10-38\% și respectiv 6-36\%, comparativ cu proba martor. Analizând rezultatele obținute putem deduce, că pentru stimularea procesului de biosinteză a pigmenților carotenoizi concentrația eficientă a nanoparticulelor $\mathrm{ZnO}(<50 \mathrm{~nm})$ este de $10 \mathrm{mg} / \mathrm{L}$. În cazul monitorizării valorilor cantitative a pigmenților carotenoizi sub influența nanoparticulelor $\mathrm{ZnO}(<100$ $\mathrm{nm}) \mathrm{s}$-a constatat efect pozitiv asupra biosintezei pigmenților carotenoizi la aplicarea concentrației 10 $\mathrm{mg} / \mathrm{L}$ care induc o creștere moderată cu $10 \%$, comparativ cu varianta control. Generalizând rezultatele obţinute în acest studiu putem menţiona, că nanoparticule $\mathrm{ZnO}(<50 \mathrm{~nm})$ în concentrații de $10 \mathrm{mg} / \mathrm{L}$ prezintă un factor preferențial de aplicare în tehnologia de cultivare a levurii Rhodosporidium toruloides CNMN-Y-30, din punct de vedere al sporirii cantităţii de pigmenți carotenoizi. 